\title{
THE DEMOGRAPHIC CHALLENGE OF THE INTERCONNECTED EDUCATION AND PENSION SYSTEM IN THE CZECH REPUBLIC
}

\author{
Sergey Slobodyan \\ Viatcheslav Vinogradov
}
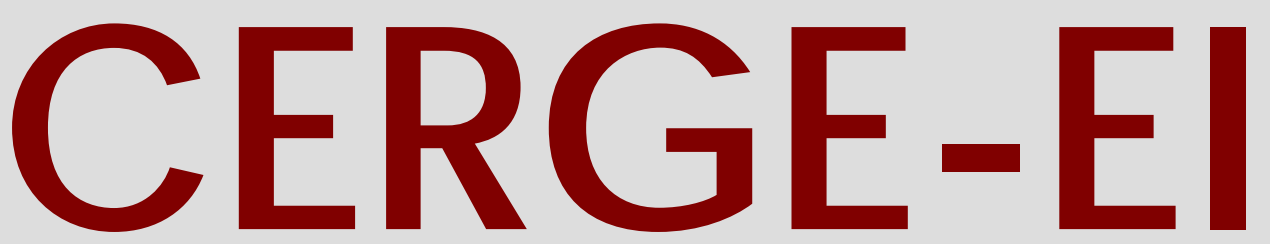

Charles University CenterforEconomic Research and Graduate Education Academy of Sciences of the Czech Republic Ec onomic Institute 


\title{
Working Paper Series 326 (ISSN 1211-3298)
}

\section{The Demographic Challenge of the Interconnected Education and Pension System in the Czech Republic}

\author{
Sergey Slobodyan \\ Viatcheslav Vinogradov
}

CERGE-EI

Prague, April 2007 
ISBN 978-80-7343-125-9 (Univerzita Karlova. Centrum pro ekonomický výzkum a doktorské studium)

ISBN 978-80-7344-114-2 (Národohospodářský ústav AV ČR, v.v.i.) 


\title{
The Demographic Challenge of the Interconnected Education and Pension System in the Czech Republic
}

\author{
Sergey Slobodyan and Viatcheslav Vinogradov*
}

\begin{abstract}
CERGE-EI ${ }^{\dagger}$
Abstract

In their recent paper, Boldrin and Montes (2005) analyze the "return on human capital investment" theory and show that if borrowing for education is not possible, then a combined public education and pension system that uses lump sum taxes and transfers can replicate the first-best decentralized allocation achieved in an economy without taxes where borrowing for human capital accumulation (education) is allowed. Taking into account that such borrowing is either absent or inefficient in many countries, a combined public education/public pensions scheme in such countries might prove to be welfare enhancing. Guided by this theoretical framework, we calibrate the parameters of an interconnected pension and education system for the Czech Republic under different demographic scenarios and fiscal rules. We also model the impact of an increase in the retirement age and of a hypothetical imbalance of pensions or educational transfers.
\end{abstract}

\begin{abstract}
Abstrakt
V nedávném článku Boldrin a Montes (2005) analyzují teorii "výnosu z investic do lidského kapitálu" a ukazují, že když nejsou možné půjčky na vzdělání, může kombinace veřejného vzdělávání a penzijního systému, který používá daň z hlavy a transfery, replikovat nejlepší decentralizované rozdělení investic získané v ekonomice bez daní, kde je umožněno vypůjčit si za účelem akumulace lidského kapitálu (vzdělání). Když vezmeme v úvahu, že možnost takových půjček je v mnoha zemích chybějící nebo nefunkční, kombinovaný veřejný vzdělávací a penzijní systém může vest ke zvýšení blahobytu. V naší stati používáme tento teoretický rámec ke kalibraci parametrů propojeného penzijního a vzdělávacího systému pro Českou republiku v několika různých scénářích demografického vývoje a daňové politiky. Také modelujeme vliv zvýšení věku odchodu do důchodu a hypotetického znerovnovážnění důchodů nebo př́spěvků na vzdělávání.
\end{abstract}

Keywords: Public education, demographic development, pay-as-you-go pensions JEL classification: H52, H55, I22, I28, J11, J26

\footnotetext{
The authors gratefully acknowledge funding from the Global Development Network RRC IV Grant and thank discussants and participants at the GDN RRC 2004 conference in Prague, seminar participants at CERT in Edinburgh, and the Economic Growth workshop in Copenhagen for valuable comments and suggestions. The standard caveat applies.

*Sergey.Slobodyan@,cerge-ei.cz, +42 224005 211.Viatcheslav.Vinogradov@,cerge-ei.cz, +42 224005 234. Fax +42 224227 143. CERGE-EI, Politickych veznu 7, 11121 Prague 1, Czech Republic.

${ }^{\dagger}$ CERGE-EI is a joint workplace of the Center for Economic Research and Graduate Education, Charles University and the Economics Institute of the Academy of Sciences of the Czech Republic.
} 


\section{Introduction}

A theoretical and empirical literature exists (see Boldrin and Montes, 2005) on the theory referred to as "return on human capital investment" (Mulligan and Sala-i-Martin, 2004), which researches the relationship between human capital investment (e.g. public education) and pension systems, and it considers a public pension to be a return on the investment into the human capital of the next generation. The generation of current retirees made an investment when they were middle-aged by paying taxes which were partially used to educate their offspring. In turn, the debt incurred by the young for being educated through this system is repaid through their own social security contributions when they become middle-aged. In a pay-as-you-go pension system, these contributions would be transferred to the elderly as pensions. An interconnected pension and public education system can replicate the allocation achieved by complete markets, where the young can borrow against their future income. The two systems are connected through implicit rates of return on public schooling expenditures and educational taxes. This scheme is equivalent to intergenerational transfers among three generations: the young, the old, and the middle aged. ${ }^{1}$ The "return on human capital investment" theory could be thought of as generational accounting (see e.g. Auerbach, Kotlikoff and Leibfritz 1999) from an individual perspective.

Boldrin and Montes (2005) further calibrate their model to Spanish data. The normative prediction of the model is that the implicit rate of return $\boldsymbol{i}$ that equalizes the discounted values of educational services received and social security contributions paid equals the implicit rate of return $\boldsymbol{\pi}$ that equalizes the discounted values of educational taxes paid and social security benefits received. Finally, both $\boldsymbol{\pi}$ and $\boldsymbol{i}$ equal the market interest rate. The authors show that this normative prediction approximately holds in the Spanish case if one assumes that the institutional structure of the public education and pension systems in the last 20 years are in effect for all living cohorts. They further extrapolate

\footnotetext{
${ }^{1}$ Alternative financing schemes proposed by Boldrin and Montes (2005) include a special proportional tax on capital or a special debt instrument. Without lump-sum taxation, the replication of the complete markets allocation becomes impossible, though it is still possible to approximate it even when markets are incomplete and private borrowing to finance education is not available. The analysis is very promising because even in developed countries the markets for financing the accumulation of human capital (education) through borrowing against future labor income are not very advanced; it sheds light on ways
} 
their model into the future, using demographic projections and various assumptions on the behavior of taxes and expenditures over time. The projections reach two conclusions: First, demographic evolution moves the two implicit rates of return apartindividuals receive a higher rate of interest through pensions than they pay through social security contributions, and second, rates of interest paid or received by different cohorts do not monotonically depend on the year of birth. The joint consideration of education and pension systems proposed by the authors does not lead to a systematic transfer of resources from the currently young and not-yet-born generations to the currently old, as the usual conclusion in the generational accounting methodology finds.

We apply this theoretical framework to calibrate an interconnected pension and education system in the Czech Republic under different scenarios of demographic and economic development. Both systems are undergoing deep changes, and the study proposed here might prove to be useful in informing policymakers about the desirable direction for reforms of both systems and estimating the magnitude of such reforms. In particular, it is important to understand the impact of any possible changes on the structure of funding in higher education and/or pension benefits. For instance, while higher education in the Czech Republic is at present mostly free, parts of the political spectrum propose to increase the extent of private funds used. A scheme with more private funding suggests a less costly transfer to a system where education is not "free" but represents an explicit individual asset with corresponding liabilities (provided such a system is socially optimal and politically feasible). Another crucial qualitative exercise is to assess the impact of an increase in the retirement age that is a key part of the pension system reform currently under way in the Czech Republic. We scrutinize these issues empirically by looking at Czech Microcensus data from 1996 and 2002.

The paper is organized as follows: Section 2 provides a description of the data and a discussion of the empirical methodology applied in our analysis. Section 3 presents the simulation results. Finally, Section 4 concludes with a summary of the findings and a discussion of policy tools that could be used to achieve efficiency and fairness in intergenerational transfers.

to complete important markets. See Patrinos (2002) for a survey of observed institutional arrangements 


\section{Empirical Framework}

We first attempt to estimate the net present value of transfers that were paid and received by every currently-living cohort in the Czech Republic. Note, however, that such an estimate involves a stationarity assumption that might have been justified in the Spanish case studied by Boldrin and Montes (2005) where both the public school and the social security systems were relatively stable over the last 20 years. However, this could be somewhat unrealistic for transition countries where the real values of both education and pension expenditures have varied greatly since $1989 .^{2}$ Therefore, this calculation will serve mainly as a crude benchmark for forward-looking projections.

Given the share in taxes/pensions/education transfers for each cohort, one could determine the net present value (NPV) of publicly provided education, social security taxes and the taxes used to pay for educating the next cohorts, and social security pensions. The calculation of these net present values requires a knowledge of period-toperiod survival probabilities (available from standard mortality tables) and of the interest rates. Forward-looking projections also require some assumptions regarding the future fiscal policy (in particular, social security contributions and payments, and public expenditures on education).

A forward-looking prognosis provides an evaluation of the NPV of contributions to and services from the public education and pension systems. An implicit rate of return along the life cycle that is paid on the debt incurred by going to school is the interest rate that equalizes the NPV of educational services and of social security contributions, while the implicit rate received as pensions is the one at which the NPV of education taxes equals the NPV of pensions received. For computational purposes, both implicit rates could be taken as a constant spread over or below the projected market interest rate. The results

\footnotetext{
around the world and Saint-Paul and Verdier (1993) for a theoretical analysis.

${ }^{2}$ For instance, the Czech Republic implemented its first pension reform in 1990, another transformation of the pension system is currently being discussed by the Czech government, the Czech educational system experienced a shift of resources in the state budget towards secondary vocational schools after 1995-96, etc.
} 
of the forward projection would then be cast in terms of a spread between the market interest rate and the two implicit rates of return.

To compute these implicit rates, we use Czech Microcensus-1996 and -2002 as a primary source. The size of Microcensus-1996 is 72,245 (including 34,937 males), while the Microcensus-2002 is somewhat smaller, covering 19,002 individuals, out of which 9031 are males. For each individual in the sample we compute the amount and value of public education received, the amount of taxes and pension contributions paid, and the amount of public pensions received.

The pension is defined as the sum of age pension and (if any) widow(er) pension received by an individual (orphan pensions, disability pensions, etc. are not included). We assume that all pensions are coming from the state pension fund (i.e. private pension funds can be neglected; this assumption was fully legitimate under socialism and is still applicable, by and large, in the Czech Republic).

To evaluate transfers made by an individual to the budget in the year of a Microcensus, we use the difference between gross income and net income reported by the individual in the Microcensus, combined with the VAT payment projected as a fraction of an individual's gross total money income (according to the Czech Statistical Office, the percentage of income paid as VAT varies from 9.8 percent for the highest gross income decile to 12.2 percent for the lowest decile). ${ }^{3}$ While computing per-capita social security and tax payments, and education and pension transfers, we follow the methodology of Boldrin and Montes (2005). As the best available source of information, we employ Microcensus data that may be biased in the sense that statistically, certain age cohorts are under-represented (e.g. students) and some are over-represented (e.g. retirees) as compared to the demographic pyramids. However, by normalizing the above per-capita values for each cohort to the Microcensus shares of this cohort, we correctly measure the "participation rate" of each cohort in tax and social security contributions and in education and pension transfers.

Figures on income taxes, pensions and social security payments are taken directly from the Microcensus. Education transfer is a constructed variable: The Ministry of

\footnotetext{
${ }^{3}$ We do not include corporate and excise taxes because the former is irrelevant to our model, and the latter is relatively small and would not affect the simulation results.
} 
Education, Youth, and Sport of the Czech Republic provides information on expenditures per student by type of school (nursery, basic, gymnasium, secondary vocational, secondary professional, and university). Further, from the same source we compute that in 1996 (2002 in parentheses), 4.4\% (7.3\%) of children aged 0-2 years attended nursery schools, while among children aged 3-6 years this proportion reached $90.0 \%(87.5 \%)$; also, out of a pool of students enrolled in secondary education, $42.5 \%$ (36.2\%) study in secondary vocational schools, $19.5 \%(25.2 \%)$ in gymnasia, and $38.0 \%$ $(38.6 \%)$ in secondary professional schools (SOŠ in Czech). Combined with information on the education type coded in the Microcensus as 'no education or incomplete elementary', 'elementary', 'incomplete secondary or secondary without leaving diploma (maturita)', 'complete secondary with leaving diploma (maturita)', and 'high school (including Bachelor, Magisterial, or Doctoral degree)', these figures enable us to compute education transfers to an individual in the sample as presented in Table 1 below.

\begin{tabular}{|l|r|r|}
\hline Type of school & \multicolumn{2}{|c|}{ Educational transfers per student in CZK } \\
\hline & 1996 & 2002 \\
\hline Nursery, age 0-2 years & 951 & 2285 \\
\hline Nursery, age 3-5 years & 19456 & 27391 \\
\hline Basic, age 6-15 years & 19604 & 28939 \\
\hline Secondary, with or without maturita, age 15+ & 29711 & 38772 \\
\hline University & 69221 & 75930 \\
\hline
\end{tabular}

Table 1. Educational transfers per student by type of education in the Czech Republic in 1996 and 2002.

The methodology described above allows us to estimate the "age profiles" of taxes paid and transfers received. For instance, we know that in 1996 a typical 10-year-old received 20 times as large educational transfer as a typical one-year-old, and a typical 35 -year-old male paid approximately twice as much in taxes as a typical 24-year-old 
male. These age profiles are then kept fixed in all projections and used in simulations that are discussed in detail in the next section.

\section{Simulation Results}

Unless otherwise noted, all the results are presented for Microcensus-2002. We consider separately the total population and males alone. Our basic assumption about demographic scenarios and fiscal rules is as follows. Prior to 2005 , we fix the age structure and contributions or benefits which a typical representative of a cohort pays or receives. This counterfactual assumption allows us to derive the interest rates which are "implied" by the current structure. After 2005, the age structure and the pattern of contributions and benefits change according to the scenarios described below. We again freeze the age structure and the population size from 2100 onward.

As a benchmark we take the demographic scenario which is labeled "current": it assumes that the fertility rate (that is, the average number of children born to a female over her life span) will stay constant at the current level (1.19 in 2004). As explained in Boldrin and Montes (2005), one needs to assume a fiscal rule in order to calculate the implicit interest rates when the population is not constant. For the benchmark we use the "demand driven" fiscal rule, where the expenditures on education and pensions are fixed at the current level, and taxes are adjusted so that the government budget is balanced at all times. Time profiles of the implicit interest rates for different cohorts for the total population and males alone are presented in Figure 1.

Notably, the results are significantly different because of two factors: first, women could get early pensions depending on the number of children (see Figure 2 that plots the distribution of retirees by age and gender in Microcensus-2002), and second, males pay about $2 / 3$ of taxes while getting about $50 \%$ of pension and education transfers. For males, even counterfactual cohorts, which "lived" under the frozen age structure and fiscal rule, received less in pension benefits than they paid as taxes, with a gap between the implicit interest rates of $0.2 \%$. This gap increases dramatically for the cohorts born on the eve of the $21^{\text {st }}$ century and reaches its maximum of $3.9 \%$ for the 2019 cohort. In 
the long run, males are facing a gap of $2.7 \%$. For the whole population, counterfactual cohorts received more than they paid: the gap was $-1.6 \%$. This imbalance starts to reduce and eventually changes sign for the later-born cohorts, reaching a maximum of about $1.3 \%$ for the 2017 cohort and falling to $0.3 \%$ in the long run. Overall, the Czech system of public education and pensions seems to be approximately "fair" to the total population, and it was overly generous in the past. Considered from the point of view of a newly born male, the system is going to be highly unfair, but was approximately fair in the past.

The system in 1996 was even more unfair to "hypothetical" males: the initial gap was $0.9 \%$. Its maximum and long-run values are also projected to be slightly higher (up to $0.2 \%$ ) under the 1996 aggregate education and pension spending. This is not surprising because the total amount of money spent in the Czech Republic on pensions increased from 1996 to 2002 by more than that on education (66\% increase versus $28 \%$ not adjusted for inflation; however, education transfers per capita increased more than $28 \%$ as small post-1989 cohorts entered the school system ${ }^{4}$ ). Thus, the unfairness of the system is expected to be even larger for currently young and not-yet-born males under 1996 conditions. For the whole population, we observe that all gaps are lower in absolute value: "hypothetical" cohorts enjoyed a "free lunch" of only $-1.1 \%$, the maximum gap is achieved for the same cohort of 2017 and equals $1.1 \%$, and the longrun gap is merely $0.15 \%$. The system in 1996 was less generous, and, projected into the future, was expected to hurt future cohorts less.

A common feature of the 1996 system for both males and the total population is that all implicit rates are higher by up to 0.5 percentage points, and the interest rate $\boldsymbol{i}$ shifts more than $\pi$. We will discuss efficiency issues related to this shift below.

Very distinct gender patterns, uniformly observed in different scenarios and in both Microcensuses, can be explained by biological (longer life expectancy) and behavioral (different labor force participation rates, largely caused by childbearing) differences along with policy choices (allowing earlier retirement age for women with children). The impact of policy choices will be discussed below.

\footnotetext{
${ }^{4}$ Based on Microcensus data, we find that in nominal prices, the increase in education transfers in 2002 against 1996 for the total population was $42 \%$ ( $40 \%$ for males alone), while pensions increased by $64 \%$ (62\% for males), and gross income became larger by a mere 16 percent ( $12 \%$ for males).
} 
Until now we have operated under an assumption of an unchanged fertility rate. However, projected population dynamics play an important role in evaluating the implicit interest rates for currently alive and unborn cohorts. To exemplify this role, we repeat the above exercise under three alternative scenarios of demographic development: "highly optimistic", "moderately optimistic", and "highly pessimistic". The fertility rate in these scenarios is taken to be $1.9,1.4$, and 1.05 , respectively.

Qualitatively, the results do not change. Quantitative changes are presented in Table 2 below. As the demography improves, the maximum gap drops for both males and the population as a whole, and it falls for earlier cohorts. The long-run gap slightly increases for the total population, and remains essentially unchanged for males.

\begin{tabular}{|l|l|l|l|l|}
\hline & \multicolumn{2}{|c|}{ Whole population } & \multicolumn{2}{c|}{ Males } \\
\hline & $\begin{array}{l}\text { Largest gap } \boldsymbol{i}-\boldsymbol{\pi} \\
\text { (Year of max) }\end{array}$ & Long-run gap & $\begin{array}{l}\text { Largest gap } \boldsymbol{i}-\boldsymbol{\pi} \\
\text { (Year of max) }\end{array}$ & Long-run gap \\
\hline Highly pessimistic & $1.44(2020)$ & 0.26 & $4.05(2022)$ & 2.63 \\
\hline Current & $1.29(2017)$ & 0.33 & $3.86(2019)$ & 2.68 \\
\hline Moderately optimistic & $1.15(2013)$ & 0.40 & $3.66(2015)$ & 2.72 \\
\hline Highly optimistic & $1.10(2006)$ & 0.46 & $3.48(2009)$ & 2.71 \\
\hline
\end{tabular}

Table 2. Long-run and largest gaps between the implicit interest rates under different demographic scenarios.

Up to this point, we have considered only the "demand driven" fiscal rule. Boldrin and Montes (2005) proposed three other rules. All of them are characterized by a balanced budget of the combined pension/education system at all times. The "supply driven" rule fixes the amount of taxes paid by currently alive workers and adjusts the pension and educational transfers as the population structure changes in the future. The "educate the young" rule keeps unchanged educational transfers and social security contributions, thus fixing the implicit interest rate determining how costly the "educational loan" is. In contrast, the "compensate the old" rule fixes taxes directed to the educational system and pension benefits, thus keeping unchanged the implicit interest rate determining how 
generous the pension system is. Figure 3 presents the results for males, using Microcensus-2002 and the "current" demographic scenario.

All the fiscal rules result in large gaps, both at the maximum point for a cohort born about 2020 and in the long run. The maximum gap fluctuates between $2.2 \%$ and $3.9 \%$, while the long-run difference varies from $2.0 \%$ to $2.7 \%$. For all fiscal rules, the public pension/public education system is projected to remain unfair. As the "supply driven" and "educate the young" fiscal rules result in generally low values of interest rate, they might be considered especially inefficient, as discussed below. It is interesting to note how demographic scenarios interact with different fiscal rules. While a falling fertility rate leads to an increase in both of the implicit rates if the "demand driven" fiscal rule is used, the outcome is reversed for the "supply driven" rule. Under the "demand driven" rule, relatively few workers pay a lot of taxes to support larger retiree cohorts. As a result, a faster rate of population decline leads to very large demands on social security contributions, and thus higher $\boldsymbol{i}$. On the other hand, current workers have to educate an even smaller generation of children and get guaranteed pensions, which results in higher $\pi$. The causality is reversed when the "supply driven" rule is used. With the population rapidly declining, retirees pay fixed education transfers but have to live off social security contributions paid by smaller cohorts, leading to lower $\pi$. The same logic applies to the "educate the young" and "support the old" rules.

For the total population different fiscal rules result in qualitatively similar results, with interest rates being the lowest in "supply driven" and "educate the young" budgeting. The system is projected to be approximately "fair" in the long run for the "supply driven" and "educate the young" rules under the current/moderately optimistic demographic scenarios, and for the "demand driven" and "support the old" rules under the current/pessimistic scenarios.

In the long run the fairness of the system could be further improved if the two interest rates are equalized by unbalancing the education or pension budget. For instance, for the whole population at current fertility rates with "demand driven" budgeting and with a $10.3 \%$ increment in pensions from their 2002 levels (without a corresponding increase in social security contributions), the two interest rates will be equalized at 4.2 percent, completely closing the gap of 0.33 percentage points. This increase is not enough to 
close the gap if the demographic development is believed to be optimistic, but incidentally serves this purpose for the "highly optimistic" scenario under the "supply driven" fiscal rule. The same objective can be achieved by increasing per capita educational transfers by $7.8 \%$ without a corresponding rise in taxes, but the common interest rate now is as low as $3.8 \%$.

In the Boldrin and Montes (2005) framework, efficiency requires not only pair-wise equality of the two implicit interest rates, but also their simultaneous equality to the market interest rate. If both are above the market rate, education is too costly and human capital is not accumulated in a sufficient amount. If, on the contrary, both are below the market rate, there is too much human capital while physical capital is underaccumulated. For the Czech Republic, we estimate the marker interest rate to be close to 3 percent. $^{5}$ The usage of unbalanced pension or educational transfer adjustments, while equalizing $\mathrm{i}$ and $\pi$ in the long run, leads to different efficiency outcomes. Additionally, different unbalanced schemes might not necessarily be equally politically feasible. For instance, in the above example increasing educational spending is more efficient than raising pensions in the long run (the difference from the market rate is smaller), but the voting block of retirees and middle-aged people might make this policy unrealistic.

The last numerical exercise that we perform is to increase the retirement age. An upward shift in retirement age is a part of the pension reform which has been implemented since 1996. For males, in 2002 it was 61 years, and it is expected to reach 63 by $2016 .{ }^{6} \mathrm{We}$, therefore, increase the retirement age by two years in our simulations. In addition, in some European countries the retirement age for males is as high as 67 years, and one cannot exclude this option for the Czech Republic. Thus another round of simulations is performed with the retirement age increased by six years. In both rounds we assume that the money "saved" by such a reform is removed from the pensions/education system, and the amount of social security contributions is reduced correspondingly.

\footnotetext{
${ }^{5}$ Bond markets in the Czech Republic are very weak and illiquid. As a measure of the real interest rate, we take the average midpoint between long-term deposit and loan rates minus the 12-month CPI inflation. We average the years 1999 through 2003 in order to exclude extreme volatility in 1998, possibly related to the Czech banking crisis of 1997.
} 
Three major features of our simulations are as follows. First, the retirement age reform uniformly decreases both implicit interest rates across all demographic scenarios and fiscal rules. The change in $\boldsymbol{i}$ is larger than that in $\boldsymbol{\pi}$ for the "demand driven" rule, but this relationship is reversed for the "supply driven" fiscal arrangement. The logic is relatively simple. With the "demand driven" budgeting, the effect of increased retirement age is similar to that of improved demography, as there are more workers and less retirees. Therefore, one could say that the pension reform is necessitated by falling fertility rates, if reducing the living standards of retirees is not politically feasible (this is what the "demand driven" fiscal rule amounts to).

For "supply driven" budgeting, the mechanics are somewhat different: workers now pay a very similar amount in educational taxes, as their working life is increased by less than $5 \%$, but receive pensions later in life for a shorter period of time, which results in a much lower NPV of the pension. This drives down $\pi$. On the other hand, the value of education transfers remains the same, and it is "repaid" in a smaller amount by social security contributions that are transferred to the retirees. As this reduction is spread over a long working life, the decrease in NPV of social security contributions is less than that of pensions, which leads to a smaller downward movement of $\boldsymbol{i}$ relative to $\boldsymbol{\pi}$. For males, the effects are similar in nature, but larger in magnitude, as they pay relatively more taxes. With the "supply driven" fiscal rule, their $\pi$ even becomes negative.

Second, the sizes of the maximum gaps are reduced relative to the "no reform" environment.

Third, a 6-year increase leads to a proportional increase of all the effects observed in the case of the 2-year increase. Nevertheless, even such a dramatic reduction in retirees' living standards does not result in a significant unfairness of the pension/education system for the total population: the long-run gap is below one percentage point in all scenarios and for all fiscal rules. For males, the system could become even less fair. The effect is most dramatic when the "supply driven" rule is used: the long-run gap increases from $1.8-2.4 \%$ to $3.1-3.2 \%$, and $\pi$ now drops to anywhere between $-2 \%$ and $3 \%$, depending on the demographic scenario. On the contrary, with the "demand driven"

\footnotetext{
${ }^{6}$ See http://www.cssz.cz/duchodove/davky duch_pojisteni.asp\#starobni for the detailed design of retirement age reform.
} 
fiscal rule, an increasing retirement age of males marginally improves the fairness of the pension/education system.

Numerically, the effect of the 2- and 6-year increase in the retirement age is presented in Table 3 below for the two fiscal rules, all demographic scenarios, and both total population and males alone.

\begin{tabular}{|l|l|l|l|l|}
\hline & \multicolumn{3}{|c|}{ Whole population } & \multicolumn{2}{|c|}{ Males } \\
\hline & Long-run $\boldsymbol{i}$ & Long-run $\pi$ & Long-run $\boldsymbol{i}$ & Long-run $\pi$ \\
\hline \multicolumn{5}{|c|}{ "Demand driven” fiscal rule } \\
\hline Highly pessimistic & $3.55(2.18)$ & $3.49(2.17)$ & $4.87(3.12)$ & $2.56(0.73)$ \\
\hline Current & $3.33(2.00)$ & $3.17(1.83)$ & $4.64(2.93)$ & $2.25(0.39)$ \\
\hline Moderately optimistic & $3.02(1.74)$ & $2.74(1.37)$ & $4.32(2.66)$ & $1.84(-0.06)$ \\
\hline Highly optimistic & $2.47(1.28)$ & $2.05(0.64)$ & $3.74(2.19)$ & $1.18(-0.78)$ \\
\hline \multicolumn{5}{|c|}{ “Supply driven” fiscal rule } \\
\hline Highly pessimistic & $0.13(-0.71)$ & $0.16(-1.42)$ & $1.04(-0.08)$ & $-1.00(-3.20)$ \\
\hline Current & $0.45(-0.43)$ & $0.37(-1.19)$ & $1.37(0.20)$ & $-0.78(-2.96)$ \\
\hline Moderately optimistic & $0.89(-0.06)$ & $0.67(-0.86)$ & $1.81(0.57)$ & $-0.48(-2.62)$ \\
\hline Highly optimistic & $1.59(0.54)$ & $1.20(-0.28)$ & $2.52(1.17)$ & $0.04(-2.03)$ \\
\hline
\end{tabular}

Table 3. Effect of a 2- (6-) year increase in retirement age on long-run implicit interest rates.

\section{Conclusion and Policy Recommendations}

Using the framework developed by Boldrin and Montes, our empirical results, estimated from the Czech Republic Microcensus-1996 and -2002, indicate that if current budget rules are combined with an artificially frozen current age structure, paying for educating the next generation provides a significantly higher return (in the form of pensions) than the interest "paid" on educational loans (for males alone, the two rates are almost equal). Demographic change, however, is bound to affect the gap between the two implicit interest rates. The direction of the movement of these interest rates and the size 
of this gap over time depends on an assumed scenario of demographic development, and on the type of budgeting rules chosen (i.e. "supply driven", "demand driven", or "partially driven”).

As the population structure eventually freezes at different levels determined by assumed demographic projections, various fiscal tools can be applied to eliminate the gap between the two implicit rates of return $\boldsymbol{i}$ and $\boldsymbol{\pi}$ and make $\boldsymbol{i}$, which equalizes the discounted values of educational services received and social security contributions paid, equal with $\pi$, which equalizes the discounted values of educational taxes paid and social security contributions received.

The choice and efficiency of the applied fiscal tools is conditional on the projected demographic changes and existing budgeting rules. Even if different tools-e.g. pension adjustments or educational transfer adjustments - result in the equalization of the two implicit interest rates, the level of the common interest rate may vary. Thus, the relative efficiency of these tools would be different as well, because along with the pair-wise equality of the implicit interest rates, efficiency also requires their simultaneous equality to the market interest rate.

The most dramatic outcome of our analysis is the gender difference in the fairness of the pension/education system. ${ }^{7}$ This imbalance, in addition to biological and behavioral causes, is influenced by the fact that the Czech pension law allows earlier retirement for women with children, which makes the study more difficult than those performed for other European countries so far, e.g. Spain. Such an option does not exist in most pension systems across the globe and represents a policy variable.

We cannot speculate on the effectiveness of this scheme in encouraging fertility, which sounds plausible but is beyond the scope of this study. What is clear, however, is that the scheme affects female labor force participation to a large extent. One of the outcomes of our study is that better demography improves the fairness of the system. On the other hand, more children might mean less working women who retire earlier, which leaves males with a larger tax burden and decreases the system's fairness for them.

\footnotetext{
${ }^{7}$ We do not report results for females for reasons discussed presently. A significant difference in fairness between males alone and the total population implies an even larger difference between genders.
} 
A shortcoming of our study is that we are unable to model the labor supply decisions of females (i.e., to what extent females decrease the retirement age by having larger a number of children) as a function of the pension system. To estimate the influence of our ignorance, we ran simulations assuming the ratio of total taxes paid by males and females between 1.25 and 1.35 (Microcensus-2002 gives an estimate of 1.30, which was used in all previous simulations). The long-run gap is seen to monotonically increase in the highly pessimistic (highly optimistic) demographic scenario from 2.3 (2.4) to 2.9 (3.0) percentage points for the "demand driven" fiscal rule, and from 1.4 (2.1) to 1.8 (2.7) for the "supply driven" rule.

Thus, if reducing the gender difference in fairness is deemed to be an important goal, collecting relatively more taxes from females (either by encouraging them to increase labor force participation with potentially negative effects on fertility, or by reducing the gender wage inequality) will be more effective if the "supply driven" fiscal rule is chosen. One has to keep in mind, however, that in the case of an unfavorable demographic development, such a rule might lead to rapidly falling standards of living for the elderly and a deteriorating quality of education. Finally, if one is ready to use unbalanced fiscal adjustments to improve the fairness of the system, our results suggest that an increase in educational expenditures is likely to be more efficient than a rise in pensions. 


\section{References}

AUERBACH A. J. - KOTLIKOFF L. J. - LEIBFRITZ, W. (eds.) (1999): Generational Accounting around the World. University of Chicago Press, Chicago and London.

BOLDRIN, M. - MONTES, A. (2005): The Intergenerational State: Education and Pensions. Review of Economic Studies, vol. 72 (3), pp. 651-64.

Dávky důchodového pojištění, Starobní důchod. Česká Správa Sociálního Zabezpečení, http://www.cssz.cz/duchodove/davky_duch_pojisteni.asp\#starobni.

Demographic Yearbook of the Czech Republic. Different years, Czech Statistical Office, Prague, Czech Republic.

Main Economic and Social Indicators of the Czech Republic 1990-2002. Bulletin No. 18, Research Institute for Labour and Social Affairs, Prague, Czech Republic.

MULLIGAN, C. B. - SALA-I-MARTIN, X. (2004): Political and Economic Forces Sustaining Social Security. Advances in Economic Analysis and Policy, vol. 4, No 1, Article 5. http://www.bepress.com/bejeap/advances/vol4/iss1/art5.

PATRINOS, H. (2002): Return to Education and Private Financing Options. Mimeo.

SAINT-PAUL, G. - VERDIER, T. (1993): Education, Democracy and Growth. Journal of Development Economics, vol. 42, pp. 399-407.

Statistické ročenky školství. Different years, Institute for Information on Education, Prague, Czech Republic.

Statistical Yearbook of the Czech Republic. Different years, Czech Statistical Office, Prague, Czech Republic. 

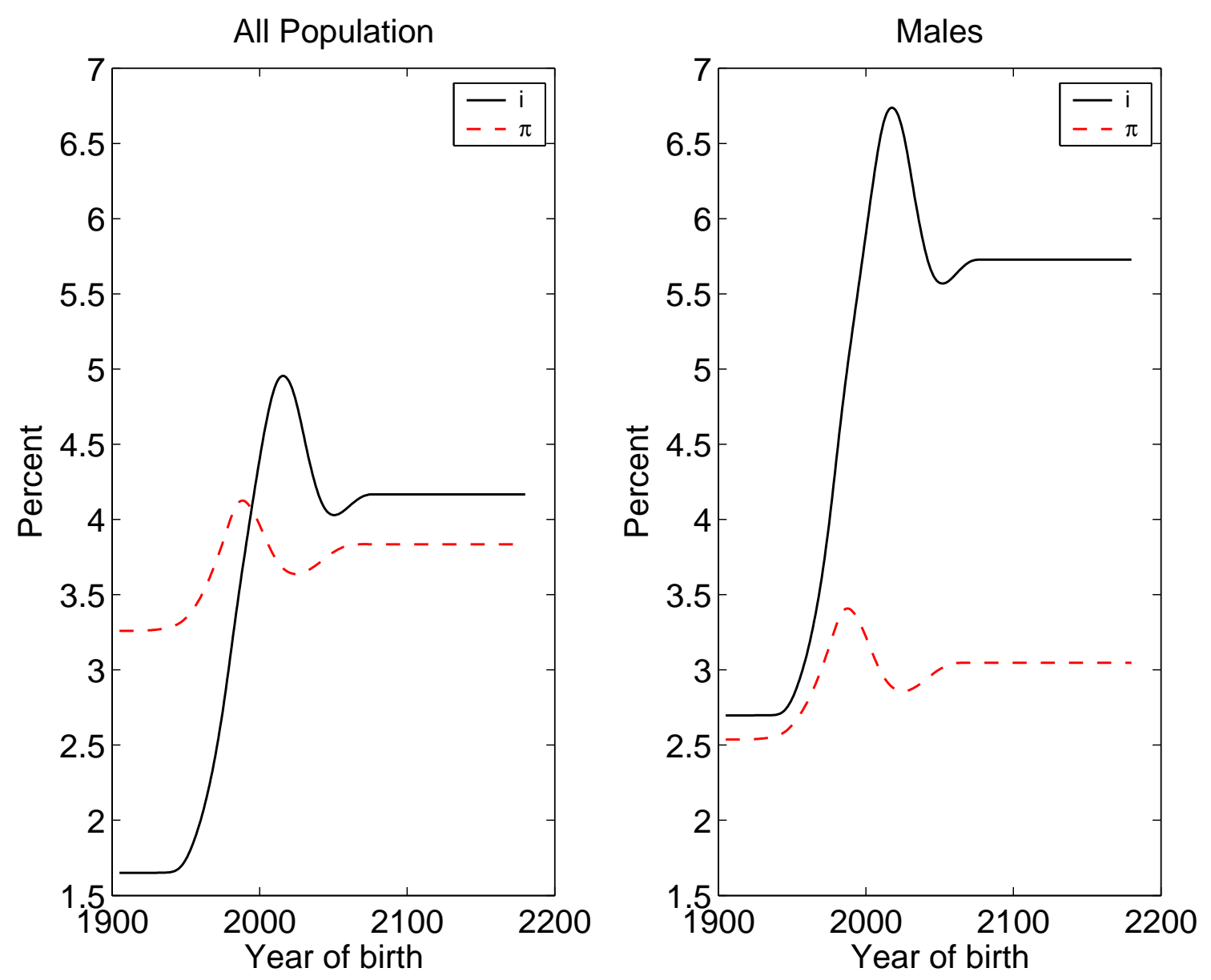

Figure 1. Implicit interest rates for the whole population and males only, Microcensus-2002 data, current demographic scenario, “demand driven” fiscal rule. 


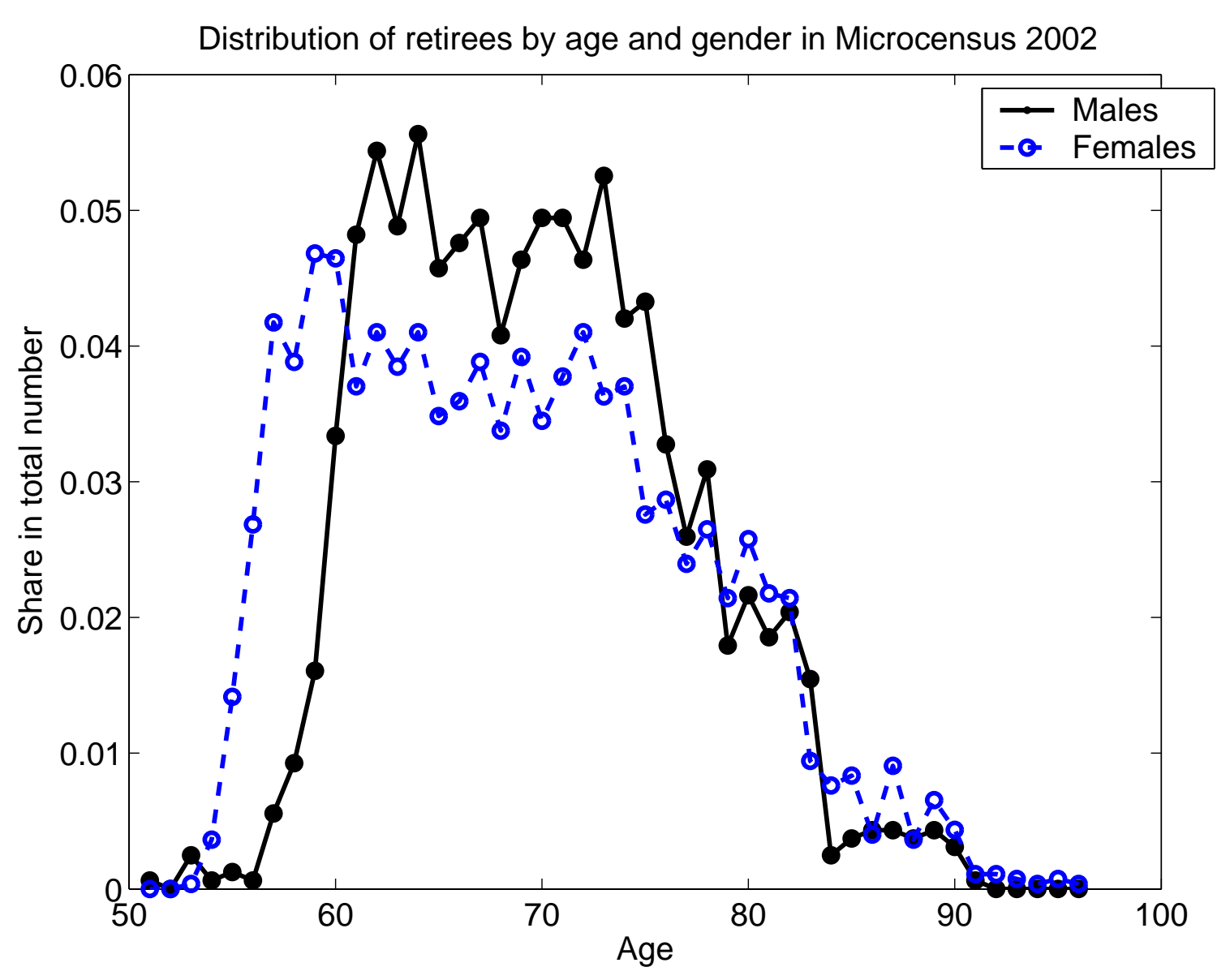

Figure 2. Shares of retirees in Microcensus-2002 by age and gender. 

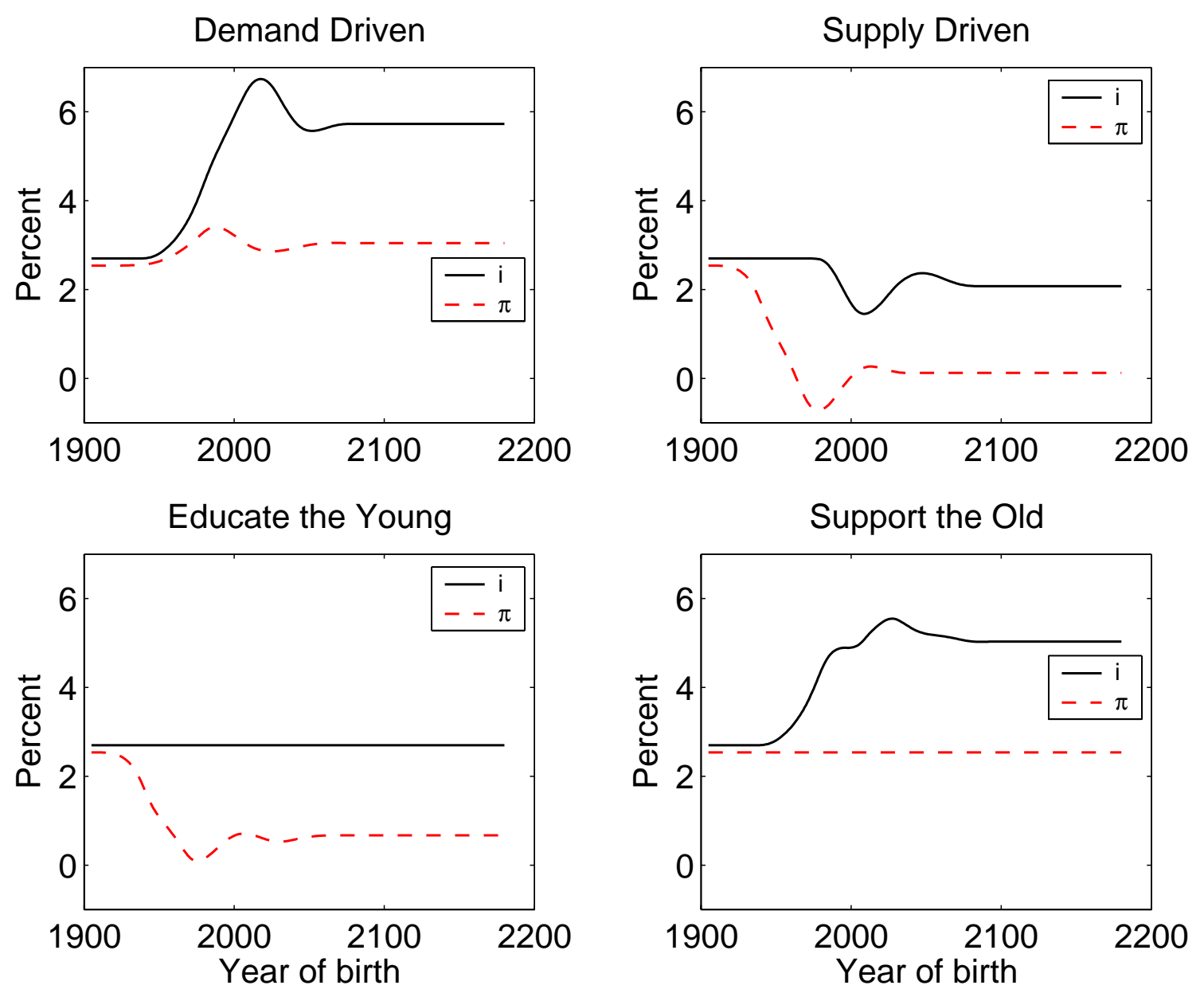

Figure 3. The behavior of implicit interest rates $\pi$ and $i$ for different fiscal rules under the current demographic scenario. Microcensus-2002 data, males only. 
Individual researchers, as well as the on-line and printed versions of the CERGE-EI Working Papers (including their dissemination) were supported from the following institutional grants:

- Economic Aspects of EU and EMU Entry [Ekonomické aspekty vstupu do Evropské unie a Evropské měnové unie], No. AVOZ70850503, (2005-2010);

- Economic Impact of European Integration on the Czech Republic [Ekonomické dopady evropské integrace na ČR], No. MSM0021620846, (2005-2011);

Specific research support and/or other grants the researchers/publications benefited from are acknowledged at the beginning of the Paper.

(c) Sergey Slobodyan, Viatcheslav Vinogradov, 2007.

All rights reserved. No part of this publication may be reproduced, stored in a retrieval system or transmitted in any form or by any means, electronic, mechanical or photocopying, recording, or otherwise without the prior permission of the publisher.

Published by

Charles University in Prague, Center for Economic Research and Graduate Education (CERGE) and

Economics Institute ASCR, v. v. i. (EI)

CERGE-El, Politických vězňů 7, 11121 Prague 1, tel.: +420 224005 153, Czech Republic.

Printed by CERGE-EI, Prague

Subscription: CERGE-EI homepage: http://www.cerge-ei.cz

Editors: Directors of CERGE and EI

Managing editors: Deputy Directors for Research of CERGE and EI

ISSN 1211-3298

ISBN 978-80-7343-125-9 (Univerzita Karlova. Centrum pro ekonomický výzkum a doktorské studium)

ISBN 978-80-7344-114-2 (Národohospodářský ústav AV ČR, v. v. i.) 
CERGE-EI

P.O.BOX 882

Politických vězňů 7

11121 Praha 1

Czech Republic http://www.cerge-ei.cz 